\title{
Molecular Characterization of $\beta$-Tubulin Isotype-1 Gene of Bunostomum trigonocephalum
}

\author{
Ravi Kumar Khare', A. Dixit ${ }^{3}$, G. Das ${ }^{4}$, A. Kumar', K. Rinesh ${ }^{3}$, D.S. Khare ${ }^{4}$, \\ D. Bhinsara ${ }^{1}$, Mohar Singh ${ }^{2}$, B.C. Parthasarathi ${ }^{2}$, P. Dipali ${ }^{2}$, M. Shakya ${ }^{5}$, J. Jayraw ${ }^{5}$, \\ D. Chandra ${ }^{2}$ and M. Sankar ${ }^{1 *}$ \\ ${ }^{1}$ Division of Temperate Animal Husbandry, ICAR- IVRI, Mukteswar, India \\ ${ }^{2}$ IVRI, Izatnagar, India \\ ${ }^{3}$ College of Veterinary Science and A.H., Rewa, India \\ ${ }^{4}$ College of Veterinary Sciences and A.H., Jabalpur, India \\ ${ }^{5}$ College of Veterinary Sciences and A.H., Mhow, India \\ *Corresponding author
}

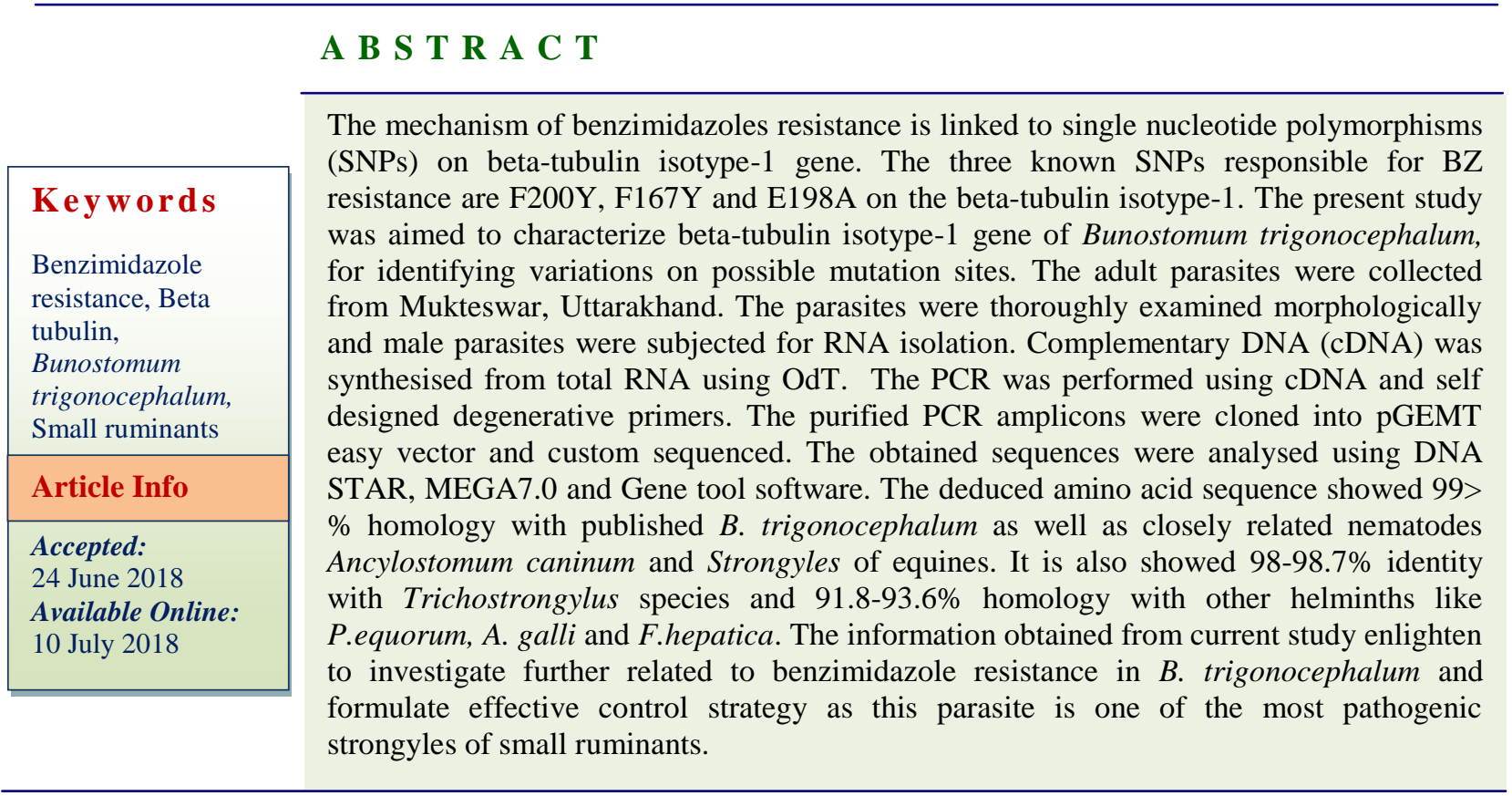

\section{Introduction}

Bunostomum trigonocephalum (Order: Strongylida, Family: Ancylostomatidae) is commonly known as hookworm of small ruminants and the infection, bunostomiasis is characterised by anaemia due to blood sucking of worm and dermatitis by larval penetration, particularly lower part of infected host (Soulsby, 1982). Few hundreds of worm can 
kill an animal (Soulsby, 1982) and Bunostomiasis is reported to be affecting all age groups, mainly of growing young ones (58 months aged). The infection is more prevalent in warm and humid regions (Tariq et al., 2008, 2010), and is also reported as major cause of economic losses in the livestock industry in temperate areas (Stancampiano, 2007). The prevalence of Bunostomum spp. is restricted in few pockets of India, mainly from central(Singh et al., 2016; Rajpoot et al., 2017), north east (Yadav and Tondon, 1989; Bandyopadhyay et al., 2010) and Kashmir valley (Tariq et al., 2008, 2010). The prevalence of $B$. trigonocephalumis very high, especially in Kashmir valley, where prevalence in sheep and goat were $37.7 \%$ and $30.1 \%$, respectively (Tariq et al., 2008, 2010).

Control of gastrointestinal nematodiasis includingbunostomiasis has achieved by using broad spectrum chemotherapeutic agents like benzimidazoles (BZs), imidazothiazoles, tetrahydropyrimidines and macrocyclic lactones. The excessive and frequent use of anthelmintics has resulted in substantial and widespread emergence of anthelminthic resistance (AR), particularly against BZin nematode populations (Kaplan et al., 2004; Garg and Yadav, 2009; Chandra et al., 2014, 2015; Dixit et al., 2017). Maximum reports of $\mathrm{BZ}$ resistance are restricted in three main gastrointestinal nematodes Haemonchus contortus. Trichostrongylus colubriformis and Teladorsagia circumcincta (Kwa et al., 1993, 1994, 1995; Silvestre and Humbert, 2000; Ghisi et al., 2007; Rufener et al., 2009; Garg and Yadav, 2009; Chandra et al., 2014, 2015; Dixit et al., 2017). BZ resistance is primarily linked to a point mutation at amino acid 200 (Phe to Tyr) (Kwa et al., 1993, 1994, 1995),167 (Phe to Tyr) (Ghisi et al., 2007) and 198 (Glu to Ala) (Rufener et al., 2009, Chaudhary et al., 2015) of $\beta$-tubulin isotope-1 gene. However, works on Bunostomum genus, particularly on the B.trigonocephalum is meager. Therefore, it is necessary to characterize $\quad \beta \quad$-tubulin gene of B.trigonocephalum for analyzing and predicting mutation pattern with respect to BZ resistance. With this aim, the present study was planned to characterize beta-tubulin isotype 1 gene of B.trigonocephalum of Mukteswar.

\section{Materials and Methods}

\section{Study area and collection of parasites}

Adult Bunostomum trigonocephalum isolate were collected from gastrointestinal tract of goats slaughtered at local abattoir at Mukteswar $\left(29^{\circ} 28^{\prime} \mathrm{N}\right.$ and $79^{\circ} 39^{\prime} \mathrm{E}, 7500$ feet above mean sea level), Uttarakhand. Parasites were washed thoroughly in PBS ( $\mathrm{pH} \mathrm{7.4)} \mathrm{and}$ identified as per the morphological keys (Johnson, 1965; Soulsby, 1982). The adult male worms were used for extraction of total RNA.

\section{Isolation of total RNA and cDNA synthesis}

Total RNA was isolated from adult male $B$. trigonbocephalum using RNeasy minikit (Qiagen, Germany) as per manufacturer's instructions. The complementary DNA (cDNA) was synthesized from the total RNA of adult male B.trigonocehalum using oligo dT primer and by using RevertAid reverse transcriptase enzyme (Thermo scientific, USA).

\section{Polymerase chain reaction for amplification of $\beta$-tubulin isotype-1 gene}

PCR was standardized to amplify the $\beta$-tubulin isotype-1 gene of B.trigonocephalum from cDNA. The open reading frame of truncated $\beta$-tubulin gene was amplified using the selfdesigned degenerative primers (forward primer 5'GCC GGW CAR TGC GGH AAC CAG 3' and reverse primer 5'GTG AAY TCC ATT TCG TCC ATA C 3') and were 
designed to amplify all the expected mutations for $\mathrm{BZ}$ resistance present in the gene such as $167^{\text {th }}, 198^{\text {th }}$ and $200^{\text {th }}$ position. The PCR mixture consisted of cDNA as template 1.0 $\mu$, Terra $^{\mathrm{TM}}$ PCR Direct Red Dye Premix $12.5 \mu \mathrm{l}$, 10 pmoles of each primer and adding nuclease water to make final volume $25 \mu \mathrm{l}$. The reaction was standardized with annealing temperature at $60^{\circ} \mathrm{C}$. The amplicons were confirmed in $1.2 \%$ agarose gel electrophoresis.

Molecular cloning, sequencing and characterization of $\beta$-tubulin gene of B.trigonocephalum

The amplicons were gel purified using Qiaquick Gel extraction kit (Qiagen, Germany) and ligated with 50ng of pGEM®-T easy TA cloning vector (Promega) in 1:3 ratios (Vector: Purified amplicons). The recombinant plasmid was transformed in to E.coli Top10 competent cells by heat-shock method at $42^{0} \mathrm{C}$ for $90 \mathrm{sec}$. The transformed culture was plated over the freshly prepared LB Amp+ X gal+ IPTG+ plates and incubated overnight at $37^{\circ} \mathrm{C}$. The positive colonies were selected using blue-white screening method ( $\alpha$-complementation) and further confirmed by colony PCR and release of desired products from vector using EcoRI enzyme by restriction enzyme digestion. Subsequently, the positive clone was inoculated in LB stab culture and custom sequenced.

\section{Genetic characterization}

Stab cultures of positive clones harbouring the desired $\beta$-tubulin gene was sent for custom DNA sequencing to Department of Biochemistry, Delhi University, South campus. The sequence information received was analyzed by using ClustalW pair distance method (DNA Star) and phylogenetic tree was constructed using maximum likelihood method (MEGA version 7.0) with published beta tubulin isotype 1 gene of
B.trigonocephalum and other related Strongylus species. The $\beta$-tubulin gene sequences of other Strongylus and other helminthes were retrieved from NCBI database and used for comparative analysis purpose.

\section{Results and Discussion}

The anterior end of B.trigonocephalum is bent in a dorsal direction; therefore the parasite is looks like hooks. The buccal capsule is triangular funnel shape opens anterio-dorsally; it has a large dorsal tooth and two short ventral teeth. There are two sub-ventral cutting plates and small pair of dorsal plates near moth opening. Large dorsalcone is characteristics of this species, which projects in to the $2 / 3$ of buccal cavity (Fig.1). The bursa of male B.trigonocephalumis well developed with small asymmetrical dorsal lobe, which is not well demarcated from lateral lobes. The spicules are spirally twisted and united posteriorly. The spicules are 0.6-0.64 mm long, slender and alate. The gubernaculums is absent (Fig.2). The morphological features of B.trigonocephalum are documented elsewhere (Johnson, 1965; Soulsby, 1982; Suresh Singh, 2003)

\section{Amplification of $\beta$-tubulin gene sequence of B.trigonocephalum}

The PCR was amplified approximately 1178 bp size fragment of $\beta$-tubulin isotype- 1 gene in agarose gel electrophoresis (Fig.3). The PCR product was purified and the concentration of purified $\beta$-tubulin gene was 32ng/ $\mu 1$.

The ligated amplicon with pGEM®-T easy TA cloning vector was successfully transformed as evidenced by appearance of desired white colonies in the LB Amp+ X gal+ IPTG+ plates and by colony PCR (Fig.4). The presence of insert was further confirmed by restriction enzyme analysis (Fig.5). 
Sequencing and genetic characterization of $\beta$-tubulin isotype-1 gene of $B$. trigonocephalum

The positive clones harboring $\beta$-tubulin gene of B. trigonocephalum were custom sequenced and analysis result revealed that the amplicon size is $1178 \mathrm{bp}$. The deduced amino acid of sequenced region of the gene consisted of all the possible and reported mutation sites for BZ resistance i.e. F167Y, E198A and F200Y. Mutation at amino acid 200 of the beta tubulin isotype-1 (Phe to Tyr) is mostly responsible for BZ resistance in H.contortus (Kwa et al., 1994; Rufener et al., 2009). However, mutations at 167 (Phe to Tyr) and 198 (Glu to Ala) are also reported to be associated with resistance in some isolates of $H$. contortus (Prichard, 2001; Ghisi et al., 2007; Rufener et al., 2009).

The characterization of beta tubulin isotype-1 gene of B. trigonocephalum revealed that the organism is susceptible to benzimidazole resistance as amino acid on 167 and $200^{\text {th }}$ position is phenylalanine, and $198^{\text {th }}$ position is glutamic acid. The sequenced genes were aligned and analysed with available $\beta$ - tubulin gene sequence of B.trigonocephalum and other Strongylus sequences (Fig.6). The betatubulin isotype-1 gene of $B$. trigonocephalum has $>99 \%$ with published sequence of same organism and much closed related parasites A.caninum and Cyathostomes.

The identity was $98-98.7 \%$ with Trichostrongylus species such as H.contortus, T.colubriformis, Cooperia pectinata and C.oncophora. Further, 91.8-93.6\% homology with other species of helminths like P.equorum, A. galli and F.hepatica. Since the $\beta$-tubulin is one of the framework proteins of the cell function, many of the amino acid will be conserved. Therefore, single mutation creates considerable functional consequences.
Phylogenetic tree was constructed with Maximum Likelihood (ML) method using Tamura-Nei model with 500 bootstrap replications to confirm the authenticity of the taxa analysed for each node. Input file was obtained by applying the BioNJ method to a matrix of pairwise distances estimated using the Maximum Composite Likelihood (MCL) approach.

A discrete Gamma distribution was used to model evolutionary rate differences and number of substitutions per site (Fig.7). For understanding the real situation of BZ resistance at field level, characterization of beta tubulin gene is pre-requisite. Characterization studies on target genes enable to identify their polymorphism, if any, which may provide great platform in formulating effective control strategies. The phylogenetic analysis of deduced amino acid sequences revealed all the isolates of B.trigonocephalum clustered in one clade with boot value more than 500and other strongyles were in another clade..

As expected B. trigonocephalum are much closed associated with strongyles of same super family such as A. canimum and also with horse strongyles $\beta$-tubulin isotype 1 sequences. The analysis also suggested that $\beta$ tubulin isotype 1 gene sequences of $B$. trigonocephalum isolates have closely related with Trichostrongyles and other helminthes clustered separately.

The study is concluded that beta tubulin isotype-1 gene of B.trigonocephalum and other trichostrongyles are highly conserved. The information of beta tubulin isotype- 1 gene of B.trigonocephalum provided an idea for development of molecular tools to diagnosis of benzimidazole resistance at the early stage in the country. 
Fig.1 Anterior end of B.trigonocephalum showing well

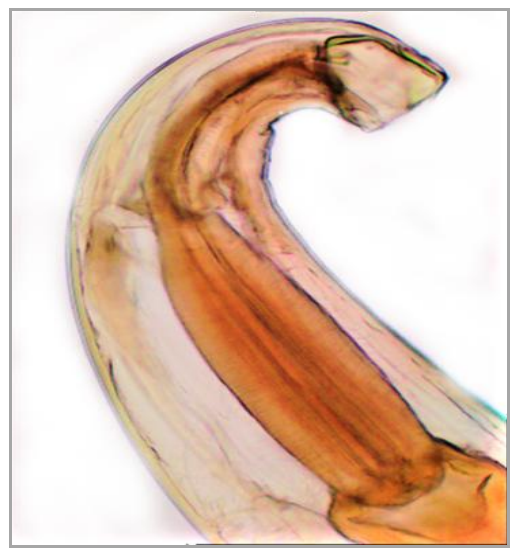

Fig.3 PCR amplification of $\beta$-tubulin gene of B.trigonocephalum Lane $M: 1 \mathrm{~kb}$ DNA ladder Lane 1\&2: $\beta$ - tubulin gene

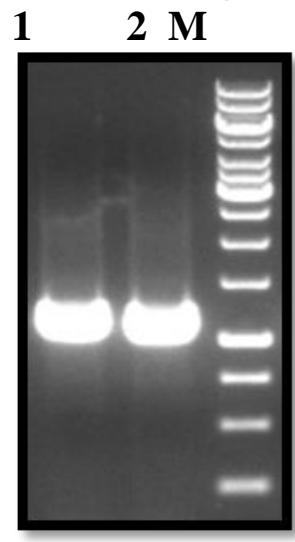

Fig.2 Posterior end of B.trigonocephalum showing spirally twisted

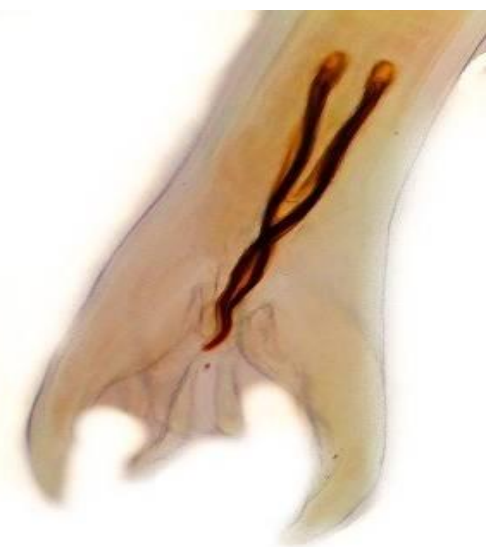

Fig.4 Colony PCR amplification of $\beta$-tubulin gene of B.trigonocephalum Lane $M: 1 \mathrm{~kb} D N A$ ladder Lane 1\&2: $\beta$ - tubulin gene

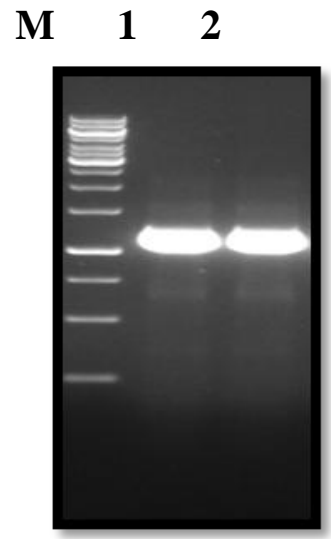

Fig.5 Release of insert from recombinant clone by EcoRI enzyme Lane M: $1 \mathrm{~kb}$ DNA ladder Lane C1-C3: $\beta$ - tubulin gene insert

\section{C1 $\mathrm{C} 2 \quad \mathrm{C} 3 \mathrm{M}$}

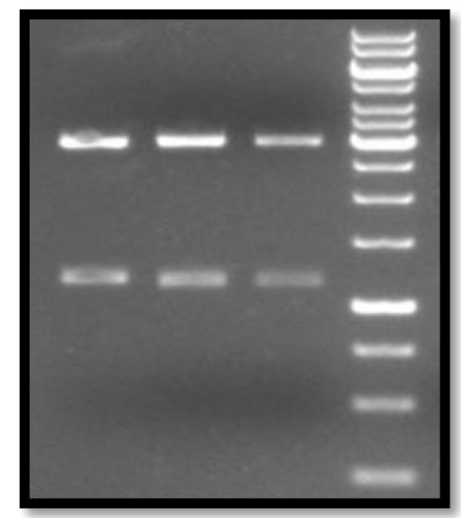


Fig.6 Pairwise relationship between B. trigonocephalum with other helminths

\begin{tabular}{|c|c|c|c|c|c|c|c|c|c|c|c|c|c|c|c|c|c|c|c|}
\hline \multicolumn{19}{|c|}{ Percent Identity } & \multirow[b]{3}{*}{ Mukteswar } \\
\hline & 1 & 2 & 3 & 4 & 5 & 6 & 7 & 8 & 9 & 10 & 11 & 12 & 13 & 14 & 15 & 16 & 17 & & \\
\hline 1 & & 99.2 & 94.1 & 99.7 & 99.0 & 98.7 & 99.7 & 99.0 & 96.2 & 99.7 & 92.3 & 98.7 & 98.5 & 98.2 & 99.2 & 94.1 & 98.5 & 1 & \\
\hline 2 & 0.8 & & 93.4 & 99.0 & 98.2 & 98.0 & 99.0 & 98.2 & 95.4 & 99.0 & 91.6 & 98.0 & 97.7 & 97.4 & 98.5 & 93.4 & 97.7 & 2 & Mukteswar Full \\
\hline 3 & 6.1 & 7.0 & & 94.1 & 94.1 & 93.9 & 93.9 & 93.1 & 93.1 & 93.9 & 91.1 & 93.9 & 94.4 & 93.4 & 93.6 & 99.2 & 93.6 & 3 & A galli Sweden \\
\hline 4 & 0.3 & 1.0 & 6.1 & & 99.0 & 98.7 & 99.5 & 98.7 & 96.2 & 99.5 & 92.1 & 98.7 & 98.5 & 98.2 & 99.2 & 94.1 & 98.5 & 4 & A caninum USA \\
\hline 5 & 1.0 & 1.8 & 6.1 & 1.0 & & 99.7 & 98.7 & 98.0 & 97.2 & 98.7 & 91.6 & 99.7 & 99.5 & 99.2 & 98.5 & 94.1 & 99.5 & 5 & C oncophora CAN \\
\hline 6 & 1.3 & 2.1 & 6.4 & 1.3 & 0.3 & & 98.5 & 97.7 & 96.9 & 98.5 & 91.3 & 99.5 & 99.2 & 99.0 & 98.2 & 93.9 & 99.2 & 6 & C pectinata BLY \\
\hline 7 & 0.3 & 1.0 & 6.4 & 0.5 & 1.3 & 1.5 & & 98.7 & 95.9 & 99.7 & 92.1 & 98.5 & 98.2 & 98.0 & 99.0 & 93.9 & 98.2 & 7 & Cst goldi UK \\
\hline 8 & 0.3 & 1.0 & 6.4 & 0.5 & 1.3 & 1.6 & 0.5 & & 95.2 & 98.7 & 91.8 & 98.2 & 97.4 & 97.2 & 98.2 & 93.1 & 98.0 & 8 & Cst longibursatus UK \\
\hline 9 & 3.2 & 4.0 & 6.4 & 3.2 & 2.1 & 2.4 & 3.4 & 3.4 & & 95.9 & 91.1 & 96.9 & 96.7 & 96.4 & 95.7 & 93.1 & 96.7 & 9 & Cyc nassatus SCOT \\
\hline 10 & 0.0 & 0.8 & 6.1 & 0.3 & 1.0 & 1.3 & 0.0 & 0.3 & 3.2 & & 92.1 & 98.5 & 98.2 & 98.0 & 99.0 & 93.9 & 98.2 & 10 & Cyc nassatus UK \\
\hline 11 & 8.1 & 8.9 & 9.5 & 8.4 & 8.9 & 9.2 & 8.4 & 7.9 & 8.7 & 8.1 & & 91.8 & 91.1 & 90.8 & 91.6 & 91.6 & 91.6 & 11 & F hepatica UK \\
\hline 12 & 1.3 & 2.1 & 6.4 & 1.3 & 0.3 & 0.5 & 1.5 & 1.0 & 2.4 & 1.3 & 8.7 & & 99.2 & 99.0 & 98.2 & 93.9 & 99.7 & 12 & H contortus BLY \\
\hline 13 & 1.5 & 2.3 & 5.8 & 1.5 & 0.5 & 0.8 & 1.8 & 1.8 & 2.6 & 1.6 & 9.5 & 0.8 & & 98.7 & 98.0 & 94.4 & 99.0 & 13 & $\mathrm{H}$ contortus MUK \\
\hline 14 & 1.8 & 2.6 & 7.0 & 1.8 & 0.8 & 1.0 & 2.1 & 2.1 & 2.9 & 1.8 & 9.8 & 1.0 & 1.3 & & 97.7 & 93.4 & 98.7 & 14 & H contortus SWITZ \\
\hline 15 & 0.8 & 1.5 & 6.7 & 0.8 & 1.5 & 1.8 & 1.0 & 1.0 & 3.7 & 0.8 & 8.9 & 1.8 & 2.1 & 2.3 & & 93.6 & 98.0 & 15 & 0 columbianum \\
\hline 16 & 6.1 & 7.0 & 0.8 & 6.1 & 6.1 & 6.4 & 6.4 & 6.4 & 6.4 & 6.1 & 8.9 & 6.4 & 5.8 & 7.0 & 6.7 & & 93.6 & 16 & P equorum Sweden \\
\hline 17 & 1.5 & 2.3 & 6.7 & 1.5 & 0.5 & 0.8 & 1.8 & 1.3 & 2.6 & 1.6 & 8.9 & 0.3 & 1.0 & 1.3 & 2.1 & 6.7 & & 17 & T colubriformis FRANCE \\
\hline & 1 & 2 & 3 & 4 & 5 & 6 & 7 & 8 & 9 & 10 & 11 & 12 & 13 & 14 & 15 & 16 & 17 & & \\
\hline
\end{tabular}

Fig.7 Molecular phylogenetic analysis by Maximum Likelihood method

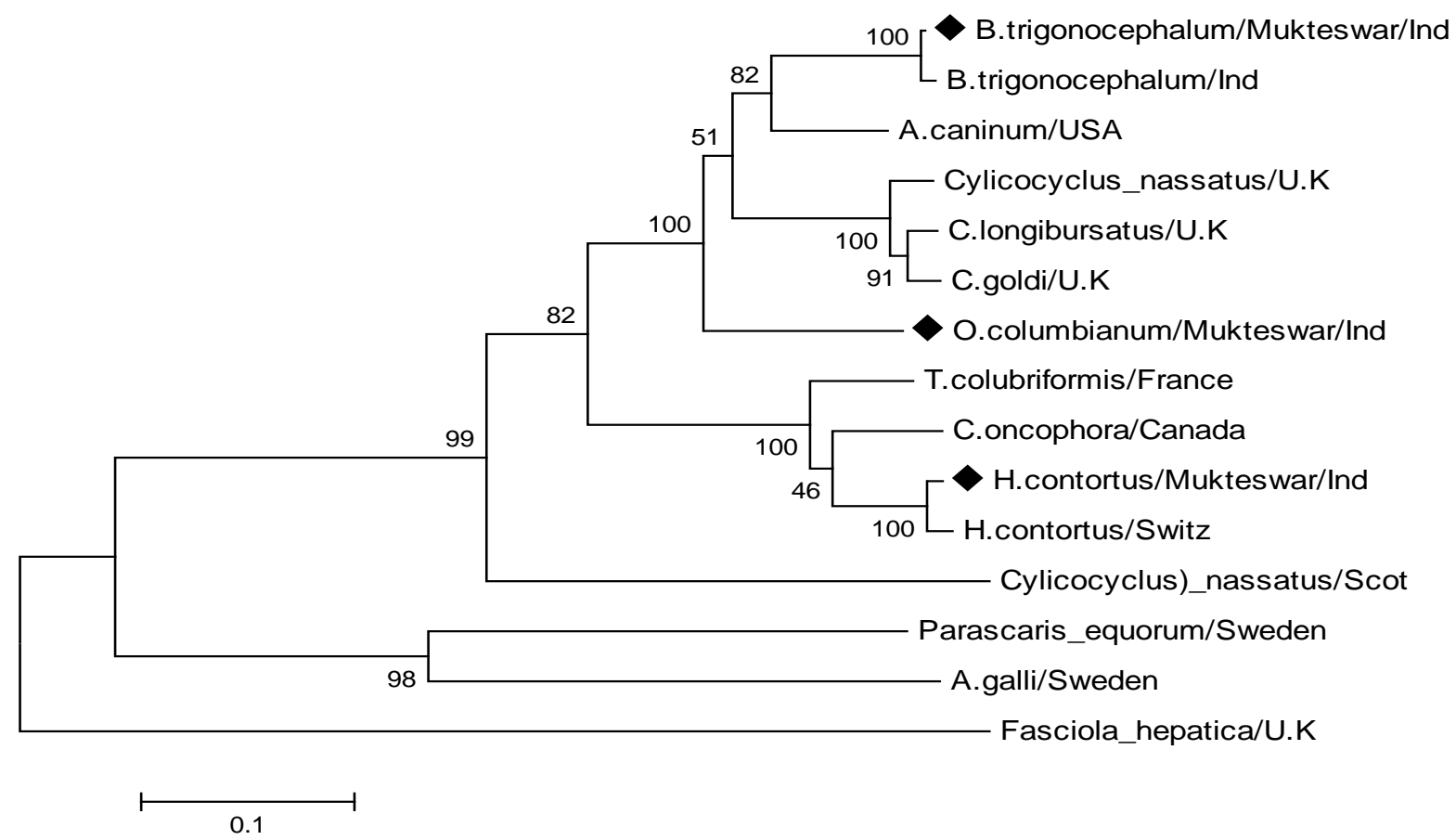




\section{Acknowledgements}

The authors are highly thankful to Indian Council of Agricultural Research (ICAR) New Delhi, India for funding through network programme on gastrointestinal parasitism, Project Coordinator of Network Programme on GI Parasitism and Director of Indian Veterinary Research Institute, Izatnagar, India for providing facilities for research.

\section{References}

Bandyopadhyay, S., Devi, P., Bera, A., Bandyopadhyay, S. and Bhattacharya, D., 2010. Prevalence of gastrointestinal parasite in goats in Shillong, Meghalaya, India. Webmedcentral.1(9):WMC00777.

Borgsteede, F.H.M., Tibben, J., Cornelissen, J.B., Agneessens, J. and Gaasenbeek, C.P., 2000. Nematode parasites of adult dairy cattle in the Netherlands. Vet. Parasitol. 89: 287-296.

Chandra, S., Prasad, A., Sankar, M., Yadav, N. and Dalal, S. 2014. Molecular diagnosis of benzimidazole resistance in in sheep from different geographic regions of North India Haemonchus contortus. Veterinary World. 7: 337-341.

Chandra, S., Prasad, A., Yadav, N., Latchumikanthan, A., Rakesh, R.L., Praveen, K., Khobra, V, Subramani, K.V., Misri, J. and Sankar, M. 2015. Status of benzimidazole resistance in Haemonchus contortus of goats from different geographic regions of Uttar Pradesh, India. Vet Parasitol. 208 (34):263-267.

Dixit, A.K., Das, G., Dixit, P., Singh, A.P., Kumbhkar, N.K., Sankar, M. and Sharma, R.L. 2017. An assessment of benzimidazole resistance against caprine nematodes in Central India. Trop Anim Health Prod. 49: 1471-
1478.

Garg, and Yadav. 2009. Genotyping of benzimidazole susceptible and resistant alleles in different populations of Haemonchus contortus from Himalayan and sub-Himalayan regions of North West India. Trop. Anim. Health Prod. 41 (7): 11271131.

Ghisi M., Kaminsky R. and Mäser P. 2007. Phenotyping and genotyping of Haemonchus contortus isolates reveals a new putative candidate mutation for benzimidazole resistance in nematodes. Vet. Parasitol. 144(3): 313-320.

Johnson, S. 1965. Observations on the systematic position of the genus Gaigeria Railliet \& Henry, 1910 (subfamily Necatorinae Lane, 1907: family Ancylostomidae Lane, 1907: Nematoda). Biol. Trop., 13(2): 213217.

Kaplan, R.M., Burke, J.M., Terrill, T.H., Miller, J.E., Getz, W.R., Mobini, S., Valencia, E., Williams, M.J., Williamson, L.H., Larsen, M., and Vatta, A.F., 2004. Validation of the FAMACHA eye color chart for detecting clinical anemia in sheep and goats on farms in the southern United States. Vet. Parasitol. 123:105-120.

Kwa, M. S., Kooyman, F. N. J., Boersema, J. H., and Roos, M. H. 1993. Effect of selection for benzimidazole resistance in Haemonchus contortus in $\beta$-tubulin isotype-1 and isotype- 2 genes. Biochem. Biophys. Res. Commun. 191: 413-419.

Kwa, M. S., Veenstra, J. G. and Roos, M.H. 1994. Benzimidazole resistance in Haemonchus contortus is correlated with a conserved mutation at amino acid 200 in $\beta$-tubulin isotype-1. Mol. Biochem. Parasitol. 63: 299-303.

Kwa, M. S., Veenstra, J. G., and Roos, M. H. 
1993. Molecular characterization of $\beta$ tubulin genes present in benzimidazole resistant populations of Haemonchus contortus. Mol. Biochem. Parasitol. 60: 133-144.

Kwa, M. S., Veenstra, J. G., Dijk, M. D. and Roos, M. H. 1995. $\beta$-tubulin genes from the parasite nematode Haemonchus contortus modulate drug resistance in Caenorhabditis elegans. J. Mol. Biol. 246: 500-510.

Prichard, R. K. 2001. Genetic variability following selection of Haemonchus contortus with anthelmintics. Trends in Parasitol. 17: 445-453.

Rajpoot, J., Shukla, S., Jatav, G.P., Garg, U.K. and Agrawal, V., 2017. Coproculture study of strongyle infection of goats from Malwa region of Madhya Pradesh.J.Entomol. Zoology studies.5 (5): 876-878.

Rufener L., Kaminsky R. and Maser P. 2009. In vitro selection of Haemonchus contortus for benzimidazole resistance reveals a mutation at amino acid 198 of beta-tubulin. Mol. Biochem. Parasitol. 168(1): 120-122.

Silvestre, A. and Humbert, J.F. 2000. A molecular tool for species identification and benzimidazole resistance diagnosis in larval communities of small ruminant parasites. Exp. Parasitol. 95: 271-276.

Singh, A.K., Das, G., Roy, B., Nath, S., and Naresh, R., 2016. Prevalence of Strongyle infections in goat of Maha Koushal region, Madhya Pradesh, India. J Parasit Dis.40 (2):289-291.

Soulsby, E. J. L. 1982. Helminths, Arthropods and Protozoa of domesticated animals. 7 th edn. Billiere

Stancampiano, L. 2007. Parasites of the digestive tract in beef cattle imported from France to Italy. Parassitologia 49(1-2):101-106.

Suresh Singh, K.R. 2003. Veterinary Helminthology, Book Published by Indian Council for Agricultural Research, New Delhi.pp379-400.

Tariq, K.A., Chishti, M.Z., Ahmad, F. and Shawl, A.S. 2008. Epidemiology of gastrointestinal nematodes of sheep managed under traditional husbandry system in Kashmir valley. Vet. Parasitol. 158:138-143.

Tariq, K.A., Chishti, M.Z. and Ahmad, F., 2010. Gastro-intestinal nematode infections in goats relative to season, host sex and age from the Kashmir valley, India. J. Helminthol. 84:93-97.

Yadav, A.K., Tandon, V., 1989. Gastrointestinal nematode infection of goat in a subtropical and humid zone of India. Vet.Parasitol. 33(2):135-142.

\section{How to cite this article:}

Ravi Kumar Khare, A. Dixit, G. Das, A. Kumar, K. Rinesh, D.S. Khare, D. Bhinsara, Mohar Singh, B.C. Parthasarathi, P. Dipali, M. Shakya, J. Jayraw, D. Chandra and Sankar, M. 2018. Molecular Characterization of $\beta$-Tubulin Isotype-1 Gene of Bunostomum trigonocephalum. Int.J.Curr.Microbiol.App.Sci. 7(07): 3351-3358. doi: https://doi.org/10.20546/ijcmas.2018.707.390 